\title{
PENGELOLAAN PELAYANAN KESEHATAN DENGAN PENDEKATAN MANAJEMEN KASUS DI PANTI WERDHA BUDI LUHUR JAMBI
}

\author{
Faridah \\ Program Studi D-III Keperawatan STIKes Baiturrahim Jambi \\ Email:faridah_rty@yahoo.co.id
}

\begin{abstract}
Case management ini one of the methods to deal with the problems that occur in the elderly. PSTW Budi Luhur jambi is a social body that cares about the elderly problem by providing health service facilities.This research is a qualitative approach. The technique used by the researcher to select the informant is purposive sampling technique, where the informant is chosen based on certain consideration and considered as the right person in giving yhe information according to the need of the informant.The result of case management reseach that is applied in PSTW Budi Luhur Jambi is very diverse starting from health problems, social problems and spirituality of elderly people. The activities undertaken with group guidance, conseling conducted by competent and counseling can be done by students who do clinical practice in PSTW Budi Luhur jambi with guidance officer lecturer supervisor. The case management phase ini PSTW Budi Luhur Jambi on the elderly problem start from assesment, implementation, controling, advication and termination
\end{abstract}

Keywords : Service Management, Case Management

\begin{abstract}
ABSTRAK
Manajemen kasus adalah salah satu metode untuk menangani permasalahan yang terjadi pada lanjut usia . Panti Sosial Tresna Werdha Budi Luhur jambi adalah lembaga sosial yang peduli terhadap permasalahan lanjut usia dengan menyediakan sarana pelayanan kesehatan. Penelitian ini menggunakan pendekatan kualitatif. Teknik yang digunakan peneliti untuk pemilihan informan adalah teknik purposive sampling, dimana informan dipilih berdasarkan pertimbangan tertentu dan dianggap sebagai orang yang tepat dalam memberikan informasi yang sesuai dengan kebutuhan informan. Hasil penelitian manajemen kasus yang diterapkan di Panti Sosial Tresna Werdha Budi Luhur(PSTW) Jambi sangat beragam mulai permasalahan kesehatan, permasalahan sosial, maupun spiritual lansia. Adapun kegiatan yang dilakukan dengan bimbingan kelompok, maupun penyuluhan yang dilakukan oleh petugas yang berkompeten dan penyuluhan dapat dilakukan oleh mahasiswa yang melakukan praktik klinik di PSTW dengan bimbingan petugas dosen pembimbingnya.Tahap manajemen kasus di PSTW Budi Luhur Jambi terhadap permasalahan lanjut usia dimulai dari Penilaian, Perencanaan Pengawasan, Pendampingan dan Pengakhiran.
\end{abstract}

Kata Kunci: Pengelolaan Pelayanan, Manajemen Kasus 


\section{PENDAHULUAN}

Lansia adalah suatu proses menghilangnya secara perlahan-lahan kemampuan jaringan untuk memperbaiki diri dan mempertahankan struktur badan fungsi normalnya sehingga tidak dapat bertahan terhadap jejas (termasuk infeksi) dan memperbaiki kerusakan yang didertita. Usia lanjut adalah seseorang yang telah mencapai usia lebih dari 60 tahun $^{1}$

Proses menua tidak dapat dihindari oleh setiap orang. Perubahanperubahan yang terjadi pada lansia umumnya mengarah pada kemunduran kesehatan fisik dan psikis. Penurunan kondisi fisik lansia ditandai dengan berubahnya penampilan, menurunnya fungsi panca indra, sehingga menyebabkan lansia merasa rendah diri, mudah tersinggung dan merasa tidak berguna lagi. Dari segi inilah lansia mengalami masalah psikologis yang banyak mempengaruhi kesehatan psikis, sehingga lansia menjadi kuarang mandiri sehingga berpengaruh pada aktivitas sehari-hari.

Selain permasalahan kondisi psikis dan fisik yang dialami lansia, masih banyak lagi permasalahan yang dialai oleh lansia seperti ditelantarkan oleh keluarga dan ada pula lansia yang membutuhkan perhatian dalam hal tata cara kehidupan. Dengan melihat permasalahan yang dihadapi lansia tersebut, maka para lansia sangat membutuhkan perhatian yang lebih dari masyarakat dan pemerintah.

Permasalahan yang dihadapi lansia memerlukan pemecahan sebagai upaya untuk menyesuaikan diri atau beradaptasi terhadap masalah dan tekanan yang menimpa mereka. Secara umum, koping dapat muncul begitu individu merasa adanya situasi yang menekan atau mengancam, sehingga individu dituntut untuk sesegera mungkin mengatasi ketegangan yang dialaminya. Individu akan melakukan evaluasi untuk memutuskan mekanisme koping apa yang seharusnya digunakan ${ }^{2}$

Ada beberapa bukti bahwa orang-orang yang dipersiapkan terhadap perubahan-perubahan psibadi dan sosial yang terjadi dimasa usia lanjut lebih mampu menyesuaikan diri terhadap kehidupan masa tua. Karena penurunan kondisi fisik dan mental lansia lebih potensi terhadap kehidupan masa tua. Karena penurunan kondisi fisik dan mental lansia lebih potensi terhadap kerawanan-kerawanan dibanding waktu lebih muda dulu. Sayangnya masyrakat sering tidakMelihat potensi tersebut, sehingga kurang ada usaha dilingkungan masyarakat untuk mempersiapkan orangorang lansia terhadap kerawanankerawanan kelak. Misalnya kurang dipersiapkan terhadap kecelakaankecelakaan (jatuh dari tangga/kamar, mandi ) atau bagaimana menghindarinya, kurang dibantu dalam penggunaan waktu luang sesuai dengan kesehatannya dan energi yang sudah menurun ${ }^{3}$

Permasalahan di panti Werdha Budi Luhur jambi sangat beragam mulai dari masalah psikis maupun fisik dan sosialnya. Permasalahan secara fisik pada lansia merupakan penurunan fungsi organ tubuh, misalnya Rematoid Arthritis, Cardiovaskuler, Hipertensi, sehingga membuat mereka tidak berdaya, namun ada juga beberapa lansia masih mampu melakukan kegiatan keterampilan yang mereka miliki walaupun daya ingat, penglihatan, pendengaran mereka sudah menurun.

Permasalahan secara psikis yang dialami lansia sangat berfariasi, seperti persaingan antara penghuni panti, tidak mau mengantri yang kadang kala dapat menimbulkan pertengkatan. Masalah ini timbul karena pada dasarnya menjadi tua akan mengalami aspek psikososial dan emosional yang tidak stabil seperti mudah tersinggung, muadh marah, merasa tidak diperhatikan, disampin itu ada juga permasalah penghuni panti dimana keluarganya tidak pernah 
menjenguk lansia di Panti, sehingga kadang kala lansia merasa sedih, Kondisi seperti ini dikhawatirkan akan berdampak ke psikis lansia lebih lanjut misalnya lansia mengalami depresei. Oleh sebab itu pihak petugas Panti werhda Budi Luhur jambi berusa menggali kasus permasalahan lansia tersebut dengan menggunakan pendekatan metode manajemen kasus agar mengetahui permasalahan lansia.

Dengan banyaknya permasalahan yang dialami lansia, maka PSTW Jambi menggunakan metode manajemen kasus untuk menghadapi serta mencari jalan keluar mengenai permasalahan yang terjadi pada lansia.

Manajemen kasus merujuk pada suatu proses atau metode yang menjamin agar klien mendapat pelayanan yang dibutuhkan secara koordinasi, efektif dan efisien. Komponen manajemen kasus yang dilakukan oleh pekerja sosial dalam menangani permasalahan lansia PSTW Jambi adalah Assesment yan mencakup identifikasi kebutuhan ( sandang, pangan, papan ), identifikasi potensi dan identifikasi masalah, perencanaan, pelaksanaan, pendampingan dan pengakhiran.

Berdasarakan latar belakang yang telah diuraikan diatas maka penulis tertarik untuk melakukan pembahasan penelitian secara mendalam mengenai gambaran " Pengelolaan pelayanan Kesehatan dengan Pendekatan Manajemen Kasus di Panti Werdha Budi Luhur Jambi.

\section{METODE PENELITIAN}

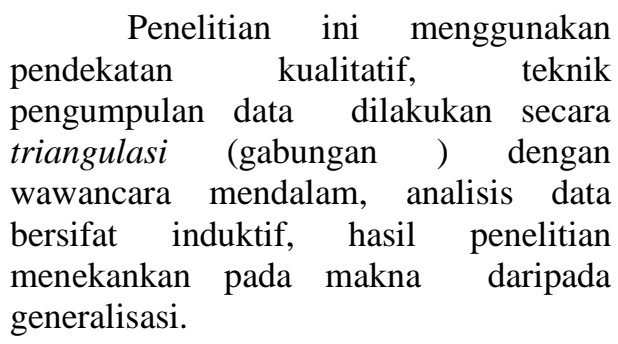

Teknik pemilihan informan adalah teknik purposive sampling dimana informan dipilih berdasarkan pertimbangan tertentu dan dianggap sebagai orang-orang yang tepat dalam memberikan informasi. Pihak-pihat tersebut yaitu pekerja sosial yang berperan sebagai pimpinan, petanggung jawab wisma, perawat. Dan 5 Warga Binaan Panti Werdha

\section{HASIL DAN PEMBAHASAN}

Manajemen kasus pada model ini broker ataupun perantara, broker ini adalah salah satu peran dan keterampilan yang dibutuhkan pekerja sosial yang berperan sebagai manajer kasus dalam menangani permasalahan yang terjadi di panti. Manajer kasus bekerjasama dengan pihak luar seperti Rumah sakit Umum Raden mattaher Jambi, Puskesmas Simpang IV Sipin,Dinas Pemakaman

Manajer Kasus dalam model ini hanya menghubungkan pasien dengan segala yang dibutuhkannya manajer kasus tidak turun langsung seperti mengantar warga binaan ke Rumah Sakit tetapi manajer kasus lebih mencarikan rumah sakit yang kosong untuk merawat pasien, namun yang mengantarkan pasien adalah perawat yang ada di PSTW . Hal ini sesuai yang dikatakan petugas di PSTW Jambi

“ Jika nenek atau kakek sakit maka pihak panti werdha menghubungkan pasien dengan cara perawat yang bertugas disini mencari Rumah sakit yang kosong apakah ada kamar kosong untuk klien"

Panti Sosial Tresna Werdha (PSTW) membuat sebuah pelayanan bagi lansia. PSTW mempunyai tujuan untuk meningkatkan taraf kesejahteraan kualitas hidup dan keberfungsian lansia sehingga dapat membuat hari tuanya bahagia dan tentram.Lansia di dalam panti lansia tidak lepas dari permasalahan seperti berselisih paham dengan tema 
sekamar, merasa sedih jika tidak di kunjungi keluarga.

Dengan melihat permasalahan ini pekerja sosial berperan sebagai manajer kasus dalam menyelesaikan masalah yang dialami lansia tersebut. Penerapan manajemen kasus diharapkan dapat mengatasi berbagai masalah, mulai dari bio, psiko,sosial dan spiritual. Karena permasalahan lansia di panti sangat beragam, dengan adanya metode manajemen kasus ini pekerja sosial dapat membantu tugas mereka seperti yang sampaikan petugas panti

" Manajemen kasus yang diterapkan di panti ini sangat beragam mulai permasalahn kesehatan, permasalahn sosial, maupun spiritual lansia. Adapun kegiatan yang dilakukan dengan bimbingan kelompok, maupun penyuluhan yang dilakukan oleh petugas yang berkompeten dan penyuluhan dapat dilakukan oleh mahasiswa yang melakukan praktik klinik di PSTW dengan bimbingan petugas dosen pembimbingnya"

Adapun tahap pelaksanaan manajemen kasus yaitu :

a. Tahap penilaian (Assesment)

Merupakan tahap untuk mengidentifikasi kebutuhan klien. Assesment adalah instrumen intelektual untuk memahami situasi psikososial klien dan untuk menentukan apa masalahnya. ${ }^{3}$ Berdasarkan hasil wawancara yang peneliti lakukan tahap ini pekerja sosial tidak langsung mengidentifikasikan masalah pasien tetapi mengidentifikasi sarana dan prasaran di PSTW Jambi., selanjutnya petugas sosial mengidentifikasi kebutuhan penghuni panti secara keseluruhan baik potensi yang dimiliki lansia maupun permasalahannya. selanjutnya petugas panti baru mengidentifikasi permasalahan yang ada di panti. Namun assesment dilakukan tidak langsung dididaptkan informasi namun untuk menggali permasalahn lansia didaptakan data secara bertahap. Sesuai yang disampaikan oleh petugas panti

" Assesmet awal dilakukan tidak langsung menanyakan permasalahan klien apa,tetapi assesment yang pertama dilakukan yaitu menggali kebutuhan klien, setelah didapatkan informasi kebutuhan klien lalu di gali potensi klien., kemudian baru kita gali permasalahan pasien, jadi untuk mengkaji permasalahn pasien tidak langsung didapatkan informasi, karen klien tidak mau langsung terbuka menceritakan permasalahannya. Namun kadangkala informasi klien didapatkan dari teman pasien. Oleh karena itu dibutuhkan pendekatan oleh pihak PSTW untuk menggali secara mendalam apa permasalah klien yang sebenarnya. Jika klien mempunya permasalahan yang komplek maka pihak PSTW dapat menyelesaikannya dengan skala prioritas"

Assesment merupakan bagian dari proses perencanaan perubahan dimana manajer kasus mempelajari kebutuhan masa kini dan yang akan datang dalam konteks permasalahan klien dari segi sosial, pekerja sosial PSTW melakukan assesment dengan metode konseling. Pada tahap ini pekerjasosial pada bagian case manager sudah mulai membuat dan membuat case record (catatan kasus) klien yang didalamnya identifikasi kebutuhan, identifikasi potensi, dan identifikasi masalah ${ }^{4}$ Identifikasi masalah yang sangat erat kaitannya dengan assesment kebutuhan (need assesment), kebutuhan dapat diidentifikasi sebagai kekurangan yang mendorong masyarakat untuk mengatasinya. Assesment dapat diartikan sebagai penentuan besarnya atau luasnya suatu kondisi dalam suatu populasi yang ingin diperbaiki atau penentuan kekurangan dalam kondisi yang ingin direalisasinkan. Fungsi assesment itu sendiri mengacu pada pengumpulan data dan perumusan assesment dari kebutuhan kebutuhan komprehensif klien, situasi 
kehidupan dan sumber-sumber. Dalam hal ini pekerja sosial juga melakukan penggalian kekuatan kan kelemahan klien.

Manajer kasus di PSTW Jambi mempunya cara tersendiri dalam mengidentifikasi klien secara tepat untuk menanganai permasalahan klien, dimana petugas sosial harus memahami masalalu klien, karena masa lalu klien, jika keluarga bisa dihubungi maka pihak PSTW melakukan home visit ke rumah keluarga klien untuk mengetahui kebenaran data riwayat hidup klien.

Adapun hasil assesment pada lansia di PSTW Jambi adalah

Nenek Martina anak tunggal berusia 78 tahun dengan status pernikahan cerai hidup . 2o yahun yang lalu suami nenek Martina meninggal dunia sekarang suami nya juga sudah meninggal memiliki anak 4 orang, tiga prang anaknya telah meninggal dunia, Nenek Martina tinggal dengan anakannya yang sedang sakit-sakitan juga, sehingga nenek martina memutuskan untuk tinggal di panti werdha karena tidak mau merepotkan anaknya, yang sedang sakitskitan. Berselang 6 bulan nenek Martin tinggal di Panti Werdha anaknyapun juga meninggal dunia. Nenek Martuna tinggal di Panti sudah 7 tahun, setiap bulan cucunya selalu menjenguk dan memeberikan uang untuk neneknya yang saat ini menderita penyakit Diabetes Melitus dan Hipertensi

Nenek Sumini berusia 82 tahun tinggal di panti werha 8 tahun yang lalu dikarenakan suami meninggal dunia karena kecelakaan. Nenek Sumia tidak mau tinggal denganenek $\mathrm{n}$ anaknya dikarenakan tidak cocok dengan anak dan menantunya sehingga memutuskan untuk tinggal di panti werdha, namun setiap minggu anaknya selalu mengunjunginya dan semua kebutuhan nenek selalu dipenuhi oleh anaknya. Akhir-akhir ini neyalami penyakit Hipertensi, gastritis dan Reumathik.
Nenek Siti Hajar berusia 64 tahun tinggal di panti werha 6 tahun yang lalu tidak memiliki saudara kandung , klien dan suaminya tinggal di gubuk kebun orang. 2 tahun yang lalu suami nya meninggal dunia dikarenakan sakit. Berhubung di tempat mereka tinggal itu akan dibangun perumahan, akhirnya dengan inisiatif warga sekitar memasukkan nenek Siti ke Panti Werdha.Kelurga yang menjenguk nenek Siti tidak ada .Saat ini nenek Siti menderita penyakit Reumatik, namun semua aktivitas dan kebutuhannnya dilakukan sendiri.

Nenek Sawiyah berusia 72 tahun dengan status pernikahan cerai. Dulunya bekerja sebagai pembantu rumah tangga di Jambi, merantau dari pulau jawa 50 tahun yang lalu. Karena tidak memungkinkan lagi untuk bekerja akhirnya majikan beliau merekomendasikan beliau untuk tinggal di panti Werdha.Klien ingin pualng ke Jawa, namuntidak tau lagi harus kemana, karena tidak memiliki keluarga . Klien di Panti sudah 10 tahun dan menemukaan jodoh kembali di Panti dan suaminya kini telah meninggal dunia.

Nenek Nursam berusia 77 tahun dengan status pernikahan cerai sudah 25 tahun yang lalu karena tidak memiliki anak. Suami klien sudah meninggal dunia.Klen bekerja sebagai pembantu rumah tangga, karena sakit dan kondisi yang tidak memungkinkan lagi untuk bekerja, akhirnya klien memutuskan untuk masuk ke panti Werdha, dengan meminta tolong petugas Dinas Sosial Kota Jambi. Klien berada di panti sudah 5 tahun. Klien sering dijenguk oleh temannya. Saat ini klien tidak bisa berjalan karena penyakit reumatik, namun utuk kekamar mandi bisa sendirian tapi tetap dibantu.

$$
\text { Dengan mempelajari }
$$

permasalahn informan 1,2,3,4,dan 5 manajer kasus melihat permasalahan 
klein secara komprehensif yaitu biologis, psikologis, sosial dan spiritual.

Tahap awal untuk menyelesaikan kasus klien petugas PSTW melakukan kontak untuk membina hubungan saling percaya, kemudian melakukan asesmen secara bertahap untuk menggali permasalahn klien. Kegiatan ini peneliti tanyakan langsung dengan petugas pembimbing klinik yaitu dalah hal pengarahan kepada mahasiswa bila melakukan pendekatan dengan lansia

$$
\text { “ Jika ingin mengetahui }
$$
permasalaahn dengan lansia lakukanlah kontak untuk membina saling percaya, dimana kegiatan ini bisa menanyakan identitas pasien terlebih dahuli, jika klien menunjukkan sika terbuka lalu petugas dapat menanyakan tentang masa lalu lansia sambil memperhatikan respon lansia, jika lansia menunjukkan sikap terbuka dapat ditanyakan ke pertanyaan selanjutnaya. Semua informasi yang didapatkan dari lansis di catat dalam catatan khusus "

\section{b. Tahap Perencanaan}

Tahap ini merupakan tahap untuk menyusun dan mengembangkan layanan yang menyeluruh untuk klien sesuai dengan hasil penilaian. Hasil-hasil identifikasi masalah yang didapatkan dari tahap penilaian. Hasil-hasil identifikasi masalah yang didapatkan dan tahap penilaian, kemudian disusun menjadi suatu formulasi masalah dan selanjutnya dapat ditetapkan prioritas masalah yang kemudian digunakan untuk menyusun perencanaan. Untuk menentukan keberhasilan program manajemen kasus yang harus dilakukan terhadap klien maka perlu disususn kriteria evaluasi ${ }^{5}$

Tahap perencanaan atau disebut rencana intervensi di PSTW manajer kasus merencanakan penenaganan kasus berdasarkan hasil assesment. Rencana intervensi disususn di dalam suatu pembahasan kasus (case conference). Dalam kegiatan ini manajer kasus mengundang kelompok profesional atau pihak yang dapat memberikan kontribusi bagi penanganan kasus seperti psikologi, ustadz, perawat, penanggung jawab wisma untuk mendiskusikan hasil assesment.

Adapun rencana untuk nenek $\mathrm{M}$ adalah melakukan kunjungan rumah (Home care) untuk mengetahui kebenaratan data yang diceritakan oleh nenek $\mathrm{M}$, menurut nenek $\mathrm{M}$ anakanya ada 4 orang, 3 orang sudah meninggal dan 1 orang anakanya sekarang lagi sakit-sakitan. Petugas panti sosial merencanakan untuk menjenguk anak nenek $M$ yang sedang sakit, disampin itu petugas sosiala menemui cucu atau saudaran klien yang bisa diajak kerja sama.

Sedangkan untuk nenek $\mathrm{S}$ rencana intervensi yang dilakukan pekerja sosial adalah tahap pertama menemui keluarganya nenek $\mathrm{S}$, menurut keterangan nenek $S$ alasan nenek memilih untuk tinggal di PSTW dikarenakan tidak cocok dengan anak dan menanntunya oleh karena itu petugas sosial berusaha mengembalikan nenek S kepada keluarganya atau membuat hubungan baik dengan keluarganya

Untuk nenek SH, nenek SW dan nenek $\mathrm{N}$ mengalami nasib yang sama dimana mereka tidak memiliki keluarga walaupun pengalamannya berbeda-beda. Oleh karena itu untuk rencana intervensi yang dilakukan manajer kasus kepada nenek tersebut adalah melihat sisi positif dan negatif dari berbagai segi mulai dari kesehatan, psiko, sosial dan spiritualnya.

c. Pelaksanaan (implementasi)

Pada tahap ini langkah yang dilakukan adalah mengidentifikasi kekuatan, masalah, sarana dan hambatan yang jelas konkrit, mereka telah membentuk kemitraan yang saling menghormati dan mencoba melaksanakan perencanaan yang telah disusun 
Panti sosial tresna werdha Jambi memberikan pelayanan kesejahteraan sosial bagi lansia terlantar dalam bentuk pembinaan fisik berupa olahraga, pemeriksaan kesehatan, rekreasipembinaan mental spiritual berupa bimbingan rohani (pengajian, ceramah keagamaan)

Pada tahap ini pekerja menejer kasus bekerjasama dengan pihak lain sesuai dengan kebutuhan klien. Manajer kasus menghubungkan klien dengan sumber yang sesuai, selain itu juga menekankan adanya koordinasi diantara umber-sumber yang digunakan/dibutuhkan oleh klieu kerjasan.

Sesuai hasil wawancara saya dengan petugas panti

" Setelah tahap perencanaan selanjutnya tahap implementasi/ pelaksanaan. Jika ada klien yang bermasalah maka manajer kasus mengidentifikasi masalah klien dan mencari pendekatan yang sesuai untuk mencari solusi dari permasalahn klien. Contohnya jika klien ingin ketemu dengan anak/cucunya maka kita akan menghubungi anak/ dan cucu nenek via telp, atau langsung kunjungan rumah. Jika keluarga tidak memiliki waktu untuk menjenguk nenek maka pihak panti sosial memberikan motivasi keluarga "

Pada dasarnya manajemen kasus merupakan kegiatan yang memiliki prosedur untuk mengkoordinasi seluruh aktivitas pertolongan yang yang diberikan kepada klien secara perorangan maupun kelompok Koordinasi di PSTW ini dilakukan dengan cara profesional team work yaitu kerjasama anatara pekerja sosial dengan profesi lain sehingga upayanya dapat di perluas terhadap peningkatan pelayanan sesuai kebituhan klien.

\section{d. Pengawasan (Monitoring)}

Menurut Marzuki dan Suharto monitoring adalah pemantauan secara terus menerus proses perencanaan dan pelaksanaan .Kegiatan monitoring dapat dilakukan dengan cara mengikuti kegiatan atau membaca hasil laporan dari pelaksanaan kegiatan. Monitoring juga dapat dikatakan sebagai proses pengumpulan informasi mengenai apa yang sebenarnya terjadi selama proses implementasi. Tujuan monitoring itu untuk :

Monitoring sering juga dipandang sebagai pengukuran kuantitas yang berkaitan dengan bagaimana pencapaian keselarasan antara sumbersumber yang digunakan dan waktu yang ditetapkan. Monitoring merupakan aktifitas yang berkelanjutan yang terutama dimaksudkan untuk memberikan informasi terhadap perencanaan dalam mengidentifikasi perubahan-perubahan yang terjadi dalam tahap implementasi. Dengan demikian dapat dikatakan bahwa monitoring pada dasarnya merupakan pemantauan suatu kegiatan atau program yang dilaksanakan pada saat kegiatan tersebut sedang berlangsung ${ }^{6}$

Adapun manajer kasus melakukan pengawasan terhadap informan 1,2,3,4,5 semua klien ini merasa betah hidup di PSTW walaupun keluarga jarang menjenguk dikarenakan menurut nenek tinggal di PSTW lebih tenang beribadah, tidak di ganggu cucu dan merasa lebih tenang hidup sendiri.

Pada tahap monitoring ini tugas amanjer kasus yaitu dengan mengawasi apakah yang diberikan kepada klien sesuai atau tidak dari perencanaan yang telah dibuat dan pelaksanaan yang sudah dijalankan.

\section{e. Pendampingan (Advocation)}

Setelah melakukan monitoring kemudian manajer kasus melakukan pendampingan atau evaluasi atas perkembangan klien baik secara fisik, psikis, dan spiritual dan hasil evaluasi ini 
akan dibicarakan dengantim manajemen kasus.. Evalauasi itu sendiri adalah mengidentifikasi keberhasilan atau kegagalan suatau rencana kegiatan atau program. Secara umum dikenal dua type evaluasi yaitu on goin evaluation (evaluasi terus menerus) dan ex-post evaluation ( evaluasi akhir). Type evaluasi yang pertama dilaksanakan pada interval periode waktu tertentu selama proses implementasi, sedangkan type evaluasi kedua dilakukan setelah implentasi suatu program atau rencana.

Dari hasil evaluasi atau pendampingan terlihat bahwa kondisi kelima klien sudah membaik dari sebelumnya.

\section{f. Pengakhiran (Termination)}

Tahap terminal adalah tahap akhir dari pemberian pelayanan kepada penerima pelayanan dalam hal ini penerima layanan adalah lanjut usia yang mengalami permasalahan baik itu permasalahan secara langsung (direct service) maupun tidak langsung (indirect service) yang disediakan oleh sistem sumber daya lain. Semua klien yang bermasalah di PSTW Jambi tidak ada terminasi kecuali pelayanan yang diberikan tidak sesuai yang dibutuhkan klien, namun mereka (klien ) masih betah berada di Panti. Jadi di PSTW pendampingannya sampai meninggal dunia dan terminasinya kalau klien meninggal dunia dan melakukan pendampingan sampai akhir hayat.

Tugas manajer kasus disini apa bila klien masih mempunyai keluarga maka majaer kasus melakukan home visit terlebih dahulu untuk mengetahui tentang keluarga klien, apakah kondisi klien akan lebih baik atau tidak ketika dipulangkan. Dan kebanyakan klien disini lebih memilih untuk berasa dipanti sampai meninggal dunia dibanding kembali ke keluarganya
Seperti yang di ungkapkan oleh ibu Evi, S.Kep

“ Pada umumnya penghuni panti permanen disini, jadi hubungan kerja kita putus ketika beliau menggal dunia, namun ada juga petugas panti melakukan home visit, namun jika keluarga klien tidak mampu untuk menampung klien, kita kasian juga, sehingga pihak panti masih menampung mereka karena sudah menjadi tanggung jawab dari pemerintah dalam hal ini PSTW Jambi”.

Kemudian manajer kasus di PSTW ini juga menjaga kerahasiaan kasus yang ditangani kecuali dengan pihak yang terkait dalam menangani permasalahan klien karena dengan dijaminnya kerahasiaan ii klien akan lebih bebas mengungkapkan permasalahan yang dihadapinya ataupun perasaan yang dirasakan.

Selanjutnya prinsip kesadaran diri petugas yang ditetapkan oleh manajer kasus, majaer kasus harus mampu mengembangkan kesadaran diri dan mengontrol dirinya agar dapat menciptakan relasi yang profesional. Meskipun manajer kasus menangani permasalahan dengan hati karena yang dihadapinya lansis sehingga penangannnya harus profesional

\section{SIMPULAN}

Model manajemen kasus dalam penerapan Expanded Broker Model yang dilakukan di PSTW Jambi dimana manajer kasus menghubungkan klien dengan segala pelayanan yang dibutuhkan klien, yaitu bekerjasama secara profesional dengan pihak panti, perawat, puskesmas, rumah sakit, penceramah agama, dinas kesehatan

Tahap manajemn kasus di PSTW

Budi Luhur Jambi terhadap permasalahan lanjut usia dimulai dari Penilaian, Perencanaan Pengawasan 
(Monitoring), Pendampingan (

Advocation), Pengakhiran (termination).

\section{SARAN}

Penambahan tenaga profesioanal di PSTW seperti psikolog, dokter, perawat, rohaniawan agar pelaksanaan manajemen kasus lebih maksimal.

Lebih menjalin kerjasama yang baik antara profesi satu dengan profesi lainnya karena dalam pelaksanaannya manajemen kasus sangat dibutuhkan kerjasama antara pekerja sosial dengan profesi lainnya untuk menyelesaikan permasalahan klien.

\section{DAFTAR PUSTAKA}

1. Notoatmojo, S. 2011, Kesehatan Masyarakat Ilmu dan Seni. Rineka Cipta. Jakarta

2. Keliat .2010. Modul Praktik Keperawatan Profesional Jiwa. Jakrta : Penerbit Buku Kedokteran EGC

3. Nihayah Zahratun. 2006. Psikologi perkembangan. Ciputat: Lembaga Penelitian UIN Jakarta

4. Albert, dkk. Buku Pintar Pekerja Sosial . Jakarta :BPK . Sunung Mulia. 2008

5. Direktorat Jenderal Pelayanan dan Rehabilitasi Sosial 2004. Pedoman Penanganan Anak Melalui Rumah Perlindungan Sosial Anak : Jakarta

6. Kementrian Sosial RI. Modul Diklat Dasar Pekerja Sosial dengan Lanjut Usia. Bandung : BBPPKS.

7. Sunarto Edi. 2005. Membangun Masyarakat Memberdayakan Rakyat. Bandung. PT Refika Aditama 